\title{
Novel Switch Adaptive Control to Improve the Efficiency of Boost Converter in Photovoltaic Systems
}

\author{
Saleh Elkelani Babaa \\ System Engineering Department, Military Technological College (Inpartnership with University of Portsmouth, UK), Muscat, \\ Sultanate of Oman \\ Email: elkelanil2@yahoo.com
}

How to cite this paper: Babaa, S.E. (2017) Novel Switch Adaptive Control to Improve the Efficiency of Boost Converter in Photovoltaic Systems. Journal of Power and Energy Engineering, 5, 1-14.

https://doi.org/10.4236/jpee.2017.57001

Received: April 24, 2017

Accepted: July 5, 2017

Published: July 8, 2017

Copyright $\odot 2017$ by author and Scientific Research Publishing Inc. This work is licensed under the Creative Commons Attribution International License (CC BY 4.0).

http://creativecommons.org/licenses/by/4.0/

\begin{abstract}
The efficiency of photovoltaic power generation is affected by the changeable weather conditions. This paper improves the efficiency of a standalone PV system over a wider range of operating conditions by employing novel switch adaptive control to an interleaved boost converter. With various loads, simulation and experimental results show that the interleaved boost converter with novel switch adaptive control offers better performance and higher conversion efficiency under changeable weather conditions.
\end{abstract}

\section{Keywords}

Photovoltaic (PV) System, DC-DC Power Conversion, Maximum Power Point Tracking (MPPT), Efficiency

\section{Introduction}

Photovoltaic (PV) generation is gaining increased importance as renewable source due to a number of advantages such as absence of fuel cost, low maintenance, and pollution-free operation [1] [2]. The energy productions of PV generators vary significantly depending upon temperature and irradiance. This is reflected on the $\mathrm{P}-\mathrm{V}$ characteristics of a solar array where insolation levels have a dramatic effect on the maximum power of the array [3] [4]. Under varying weather conditions, the photovoltaic system should continuously operate, with high efficiency at/near the maximum power point of the array. Many maximum power point tracking (MPPT) algorithms have been researched and developed alongside their optimization techniques [5] [6] [7]. However, the MPPT cannot overcome efficiency short falls in the power converter. Therefore, in order to trans- 
fer maximum power to the load, the dc-dc converter efficiency must also be improved.

Several papers have been presented to increase the efficiency of power boost converters [8] [9] [10] [11]. For example, Dwari [12] has used a common active clamp to get high efficiency with coupled-inductor interleaved boost converter, but in this topology each phase of the interleaved converter requires active clamp circuit which increases the cost, size, and complexity of the converter. A voltage multiplier cell has been used with interleaved boost converter to increase the efficiency [13], but this added extra components increasing converter's cost. Another approach of increasing the efficiency of boost converters is to reduce the losses by careful design of the passive components within the power converter [14] [15] [16] [17]. This is especially true for inductors in dc-dc converters where the designer can optimise the cross-sectional area of conductors and reduce core flux densities in order to reduce losses. However, a compromise must be reached in order to limit increases in cost, size, and weight [14]. Likewise, emerging semiconductor device technology, such as silicon carbide [18], has allowed faster switching, lower loss, and development of power converters.

One of the most commonly utilized converter topology in PV applications is the simple boost converter shown in Figure 1. The disadvantages of conventional boost converter are high voltage stress for the switch and large peak current for the power devices and passive components [19]. This problem can be overcome by using an alternative power converter topology, such as an interleaved converter [2].

The interleaved boost converter in Figure 2, comprises two limbs operating 180 degree out of phase from each other. Typically, each branch operates in the same fashion as conventional boost converter. The main rewards of the interleaved converter include lower ripple power at the output due to an effective increase in switching frequency. This allows the use of lower size of output capacitor that would be relatively large if conventional boost converter is used [20].

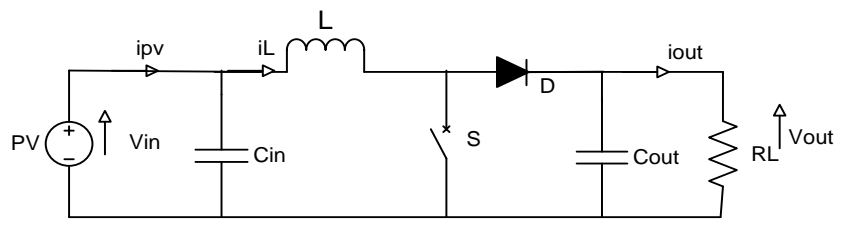

Figure 1. Interleaved boost converter.

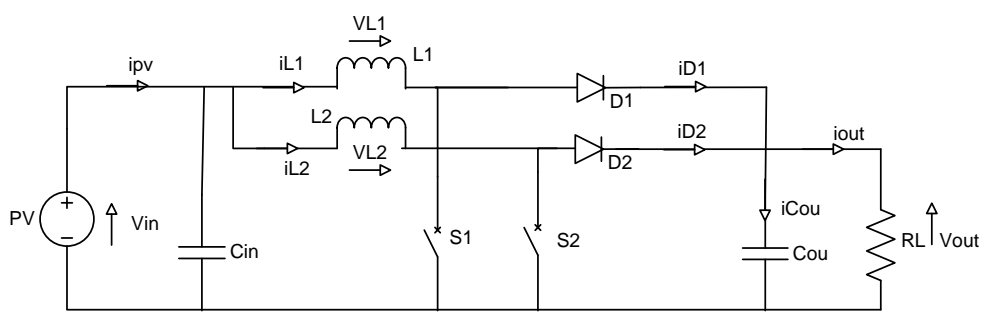

Figure 2. Conventional boost converter. 
In addition, by splitting the input current into two paths, component stress is reduced and higher efficiency is realized by substantially reducing switch and inductor ohmic losses $\left(I^{2} r\right)$ [9] [21] [22]. On the other hand, using an interleaved converter increases the number of system components which may lead to increasing in cost. However, in renewable energy systems, long term improved power generation can help to offset this disadvantage [9].

Unfortunately, operating an interleaved power converter under low power conditions can lead to discontinuous current mode (DCM) due to the split current in the separate branches. In photovoltaic applications this is a likely scenario under low irradiance conditions. In these situations, the efficiency of the interleaved converter significantly drops off and indeed a conventional boost converter may offer better performance [9].

For this reason, this research presents an interleaved power converter with adaptive switching operation control. The circuit behaves as a normal interleaved converter under high solar irradiance conditions, but under low irradiance levels the switching pattern is adjusted in real time to behave in the same way as a conventional boost converter. For a similar power rating, the current flowing in each limb of the interleaved converter is lower than a conventional dc-dc converter, hence reducing overall inductor copper losses [2] [9] [19], and also gives low stresses on component due to current split which increase power processing capability [9] [21]. Unfortunately, at low power level where the switching losses dominate, the interleaved converter will show no a drastic improvement in efficiency [12]. The conventional boost converter may offer better efficiency, in this case [9] [10] [11] [12].

This paper proposes a circuit of an interleaved boost converter with novel switch adaptive control for PV systems. The converter is tested with a PV array simulator and a different load. Perturb \& Observe ( $\mathrm{P} \& \mathrm{O}$ ) algorithm is employed for MPPT control. Converter operation in continuous current conduction mode is extended to a much lower power level. At low irradiance conditions, the control disconnects one limb of the interleaved boost converter to operate in the same way of a conventional boost converter. At high irradiance levels, the two branches of the converter are allowed to operate in interleaved mode. The performance of the proposed converter is assessed and compared with that of conventional boost converter and interleaved boost converter. The energy conversion efficiency is calculated at different operating conditions. Simulation and experimental results presented in this paper show that interleaved boost converter with novel switch control offers better performance and achieves higher power conversion efficiency with varied load and under different irradiation of weather conditions.

\section{Interleaved Boost Converter with Novel Switch Adaptive Control}

To improve the efficiency of the interleaved boost converter at low power level, a new switch adaptive control strategy is proposed as shown in Figure 3. At high 
power, it operates normally as an interleaved converter, following the switch control rules already described. However, at low power (low irradiance) one phase of the interleaved cell is isolated and all the current is controlled to flow in one phase of the interleaved converter. Fundamentally, the interleaved converter is now operating as a conventional boost converter (single inductor, single switch). At low power levels, the current is obviously low. However, by controlling all the current into one leg of the interleaved boost converter, it reduces the risk of operating in discontinuous current mode. So long as the converter operates in continuous current mode, the efficiency of the converter will be greater.

The proposed adaptive switching control as in Figure 4, measures the PV current and PV voltage to monitor the PV power and follows a very simple request to operate the converter as an interleaved boost converter (switch $\mathrm{ON}$ ) at high PV power when the power is over a 25 Watt level, and as a conventional boost converter (switch OFF) at low PV power when the PV power is lower than 25 Watts.

The controller has several advantages, it minimises system losses, and helps the interleaved converter to operate with maximum power conversion efficiency at all times, and under a wide range of atmospheric conditions. Moreover, the control scheme can be achieved with no significant additional hardware and, in terms of microprocessor implementation it is computationally light.

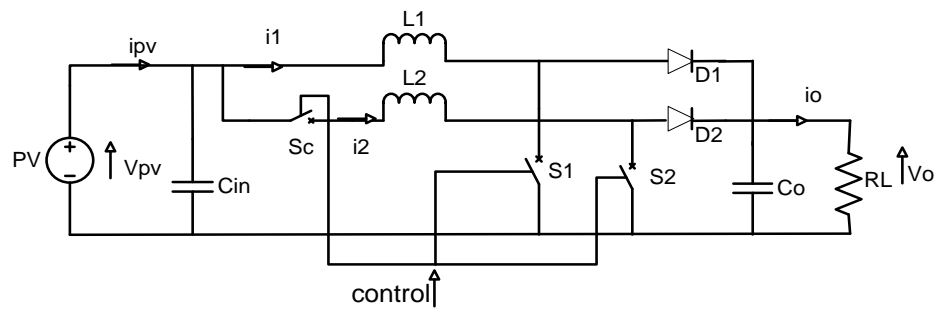

Figure 3. Interleaved boost converter with novel switch adaptive control.

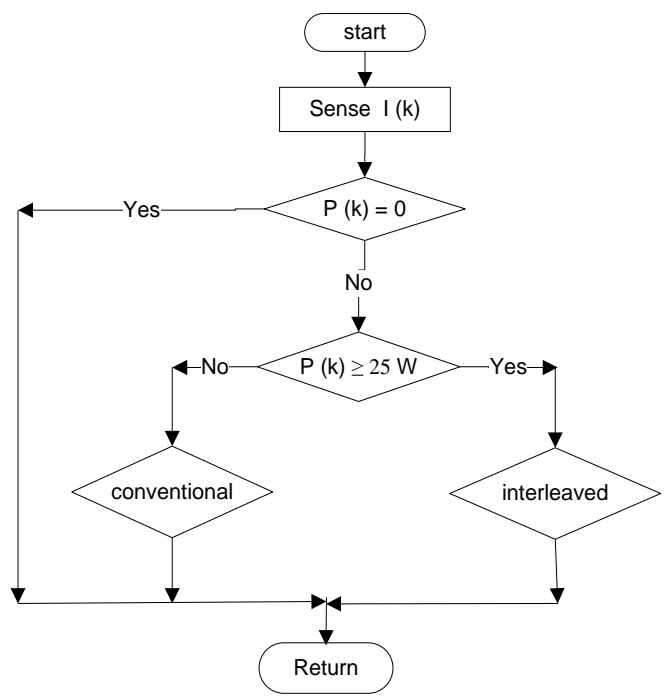

Figure 4. Flow chart of novel switch adaptive control. 


\section{Results and Discussion}

To validate the theoretical analysis of the introduced standalone photovoltaic system using a presented boost converters. A perturbation and observation algorithmis used to guarantee maximum PV power that is generated from the PV panel; also the proposed switch control is used to operate the interleaved boost converter at high efficiency all times under changeable weather. In addition, to validate the results, key design constraints and parameters are used on the presented boost converters in both the software and hardware as shown in Table 2. Both simulation and experimental are developed to evaluate the discussed boost converters with the introduced PV system as shown in Figure 5. Tests are carried out at several power levels of photovoltaic panel (KD50SE-1P; details in Table 1) under a variety of load and irradiation conditions.

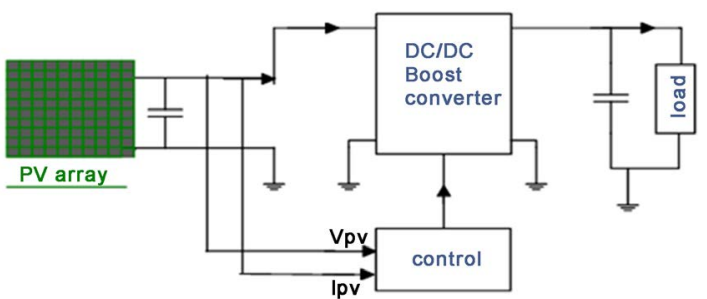

Figure 5. Block diagram of used standalone PV system.

Table 1. The key data of the KD50SE-1P PV model.

\begin{tabular}{cc}
\hline KD50SE-1P & $\mathrm{G}=1000 \mathrm{w} / \mathrm{m}^{2}, \mathrm{~T}=25^{\circ} \mathrm{C}$ \\
\hline Maximum power & $50(\mathrm{~W})$ \\
Short circuit current & $3.07(\mathrm{~A})$ \\
Open circuit voltage & $22.1(\mathrm{~V})$ \\
Max. power current & $2.8(\mathrm{~A})$ \\
Max. power voltage & $17.9(\mathrm{~V})$ \\
\hline
\end{tabular}

Table 2. Parameters for conventional, interleaved, and interleaved with novel switch control.

\begin{tabular}{ccc}
\hline Parameters & $\begin{array}{c}\text { Conventional boost } \\
\text { converter }\end{array}$ & $\begin{array}{c}\text { Interleaved boost converter, interleaved } \\
\text { with novel switch adaptive control }\end{array}$ \\
\hline Capacitor (Cin) & $9.4 \mu \mathrm{F}$ & $9.4 \mu \mathrm{F}$ \\
Inductors & $\mathrm{L} 1=1 \mathrm{mH} 1=1 \mathrm{mH}$ \\
Frequency & $20 \mathrm{kHz} 2=1 \mathrm{mH}$ \\
Capacitor (Cout) & $44 \mu \mathrm{F}$ & $20 \mathrm{kHz}$ \\
Load & Resistive, and inductive & $44 \mu \mathrm{F}$ \\
Mosfet & IPP075N15N3G & Resistive, and inductive \\
Diode & BYW29EX-200 & $2 *$ IPP075N15N3G \\
Frequency & $f=20 \mathrm{kHz}$ & $2 *$ BYW29EX-200 \\
Switch-connection $(\mathrm{Sc})$ & $/$ & $f=20 \mathrm{kHz}$ \\
\hline
\end{tabular}




\subsection{Simulation Results and Discussion}

The simulation result has considered justification need for the proposed control to isolate entirely limb two of interleaved boost converter, to see the efficiency performance of presented converters under change in irradiation condition.

The presented converters are tested firstly with resistive load $195 \mathrm{Ohm}$ and supplied by a solar array rated at 50 Watts maximum with a rising irradiation profile as shown in Figure 6(a) and Figure 6(b). As can be seen in Figure 6(c), the conventional boost shows a reduction in efficiency when the PV power reaches approximately 24 Watts, whilst the interleaved boost still shows an improving efficiency characteristic when the PV power increase. Figure 6(d) shows that the interleaved boost converter with novel switch adaptive control has a stable efficiency of around $95 \%$.

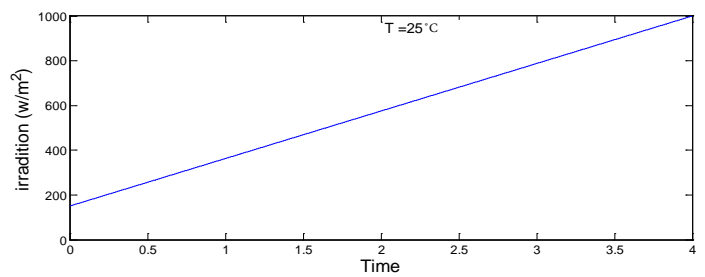

(a)

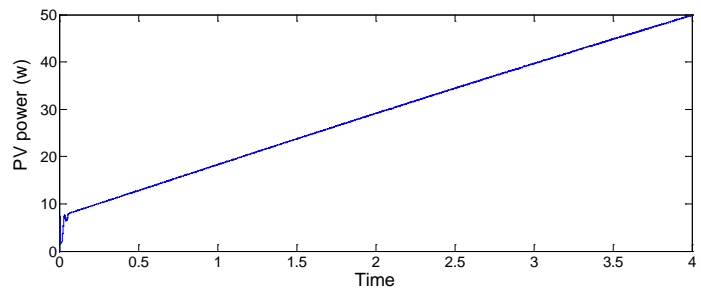

(b)

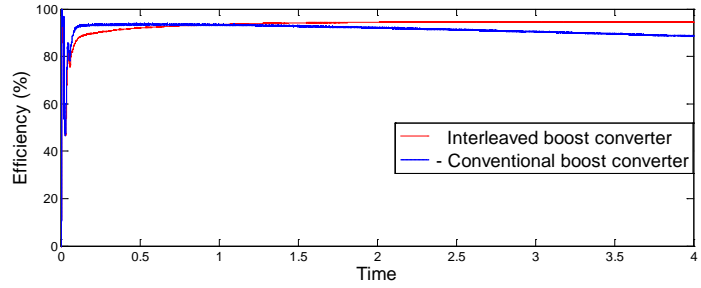

(c)

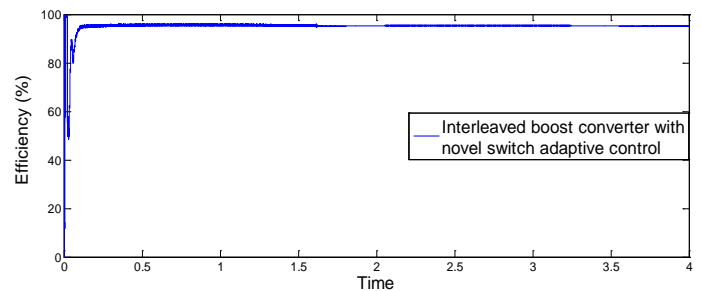

(d)

Figure 6. The PV system with resistive load (a) Irradiation in rise with $25^{\circ} \mathrm{C}$; (b) Solar panel (KD50SE-1P) power under increasing irradiation; (c) Efficiency of conventional and interleaved boost converters; (d) Efficiency of interleaved boost converters with novel switch adaptive control. 
Similarly, the introduced boost converters are tested with inductive load $(\mathrm{L}=$ $50 \mathrm{mH}, \mathrm{R}=80 \mathrm{Ohm}$ ), and supplied by a solar array of rate maximum 50 Watts with a rise in irradiation of atmospheric conditions are shown in Figure 7(e) and Figure 7(f). In Figure 7(g), it can be seen that the conventional boost shows a drop in efficiency when PV power reaches about the 25 Watt level, the interleaved boost shows a drop in efficiency when the PV power below 25 Watts and growth in efficiency level when the PV power over 25 Watts. Moreover, the graph in Figure 7(h) shows the interleaved boost converter with novel switch adaptive control has a stable high efficiency of about $95 \%$ all the time under a rise of maximum $\mathrm{PV}$ power.

\subsection{Experimental Results and Discussion}

The experimental results of the discussed boost converters are supplied with a $\mathrm{PV}$ panel of maximum power rating 50 Watts similarly. The I-V characteristics of the KD50SE-1P generated by the Matlab simulation model are then used to

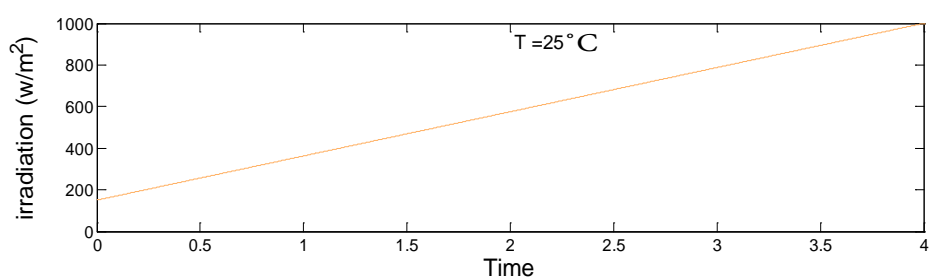

(e)

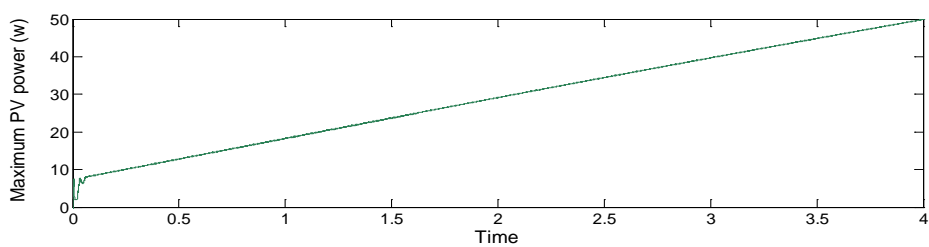

(f)

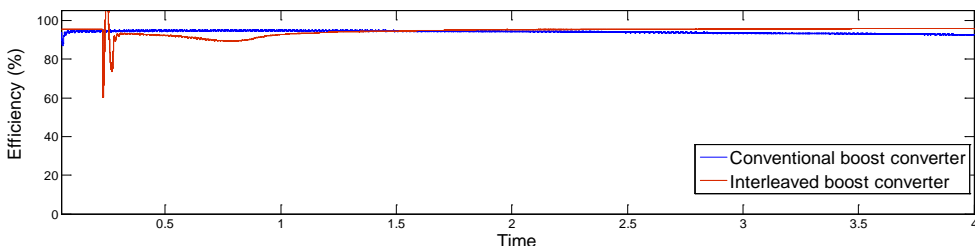

(g)

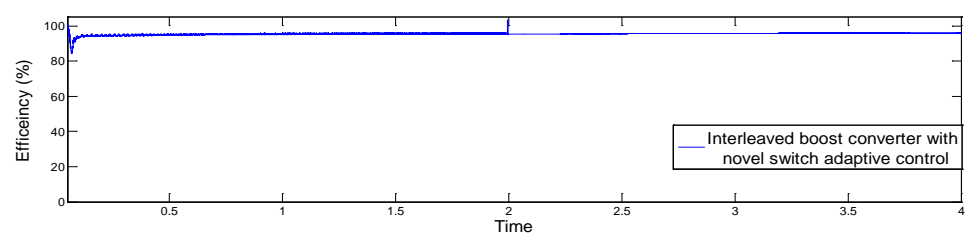

(h)

Figure 7. The PV system with inductive load (e) Irradiation in rise with $25^{\circ} \mathrm{C}$; (f) Solar panel (KD50SE-1P) power under increasing irradiation; (g) Efficiency of conventional and interleaved boost converters; (h) Efficiency of interleaved boost converter with novel switch adaptive control. 
program the TopCon DC power supply which has Solar Array Simulation (SAS) software, providing the loading, editing and storing of hundreds of current-voltage curves for the experimental work.

The solar panel is essentially a current source as the irradiation increases the current of PV will raise as well which has influence on efficiency of PV system. Therefore, discussed converters are tested with varied irradiation, $150 \mathrm{w} / \mathrm{m}^{2}$, $25^{\circ} \mathrm{C}, 500 \mathrm{w} / \mathrm{m}^{2}, 25^{\circ} \mathrm{C}, 1000 \mathrm{w} / \mathrm{m}^{2}, 25^{\circ} \mathrm{C}$.

The PWM unit generation with MPPT control in an interleaved boost converter with novel switch adaptive control is tested, when the converter is operated as a conventional boost converter (boost 1 ) and as an interleaved boost converter (boost $1+$ boost 2 ) follows the novel switch adaptive control strategy as shown Figure 8.

Solar panel acting as current source when irradiance levels increase, current of $\mathrm{PV}$ rise as well as the PV power as seen in Figure 9. At $500 \mathrm{w} / \mathrm{m}^{2}, 25^{\circ} \mathrm{C}$ as the irradiation rise, the interleaved boost converter with novel switch adaptive control starts operating with its two boosts at around 1.6 Amps [channel 2], and it shows S-switch 2 is connected by the response of designed control [channel 3], switch 2 as well connected [channel 4], and the current flow of inductor 2 [channel 1]. When the irradiation declines, current and power of PV panel do so. As seen in Figure 10, at low irradiation, the interleaved boost converter with novel switch adaptive control shows its response to the decrease of PV current below about 1.3 Amps [channel 2], PV power, by disconnect S-switch [channel 3], also switch 2 is disconnected[channel 4], and no current flow in inductor 2 [channel 1]. Results demonstrate a good dynamic control response which adapts well to power variations during to operating conditions. Furthermore, the PV voltage quality is not affected by both transition periods and no significant distortion is observed in current.

Figure 11, displays load characteristics at $1000 \mathrm{w} / \mathrm{m}^{2}, 25^{\circ} \mathrm{C}$, the figure shows the load current is 0.488 Amps with 0.0011 Amps ripple [channel 1], load voltage is 91.2 Volts with 0.21 Volts ripple [channel 4], and shows a load power is

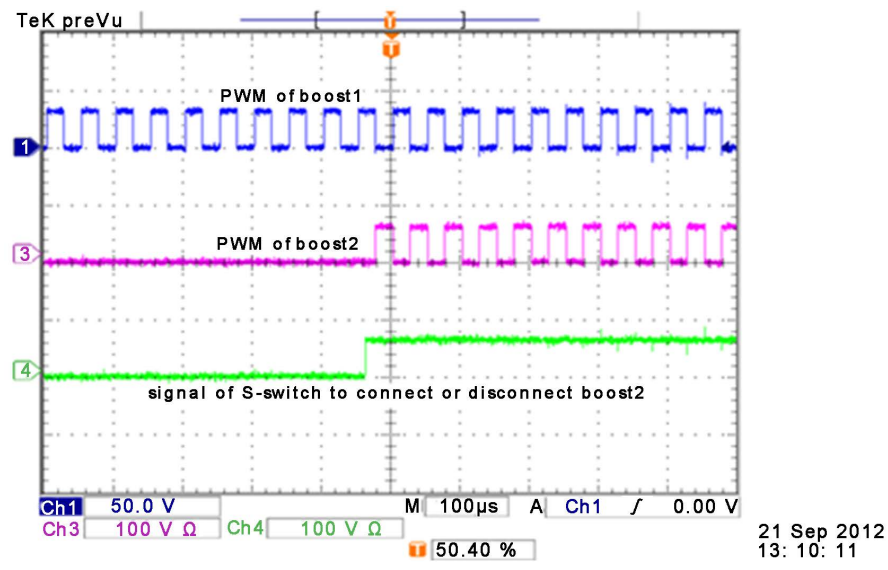

Figure 8. Interleaved boost converter switching signals with novel switch adaptive control. 


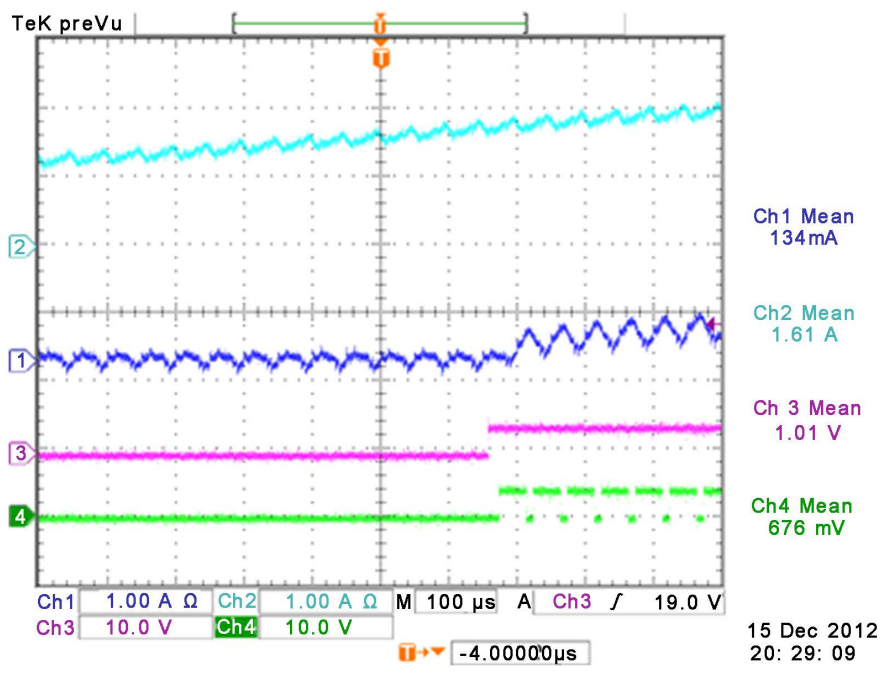

Figure 9. Response of the novel control to the PV power increase due to irradiation rise.

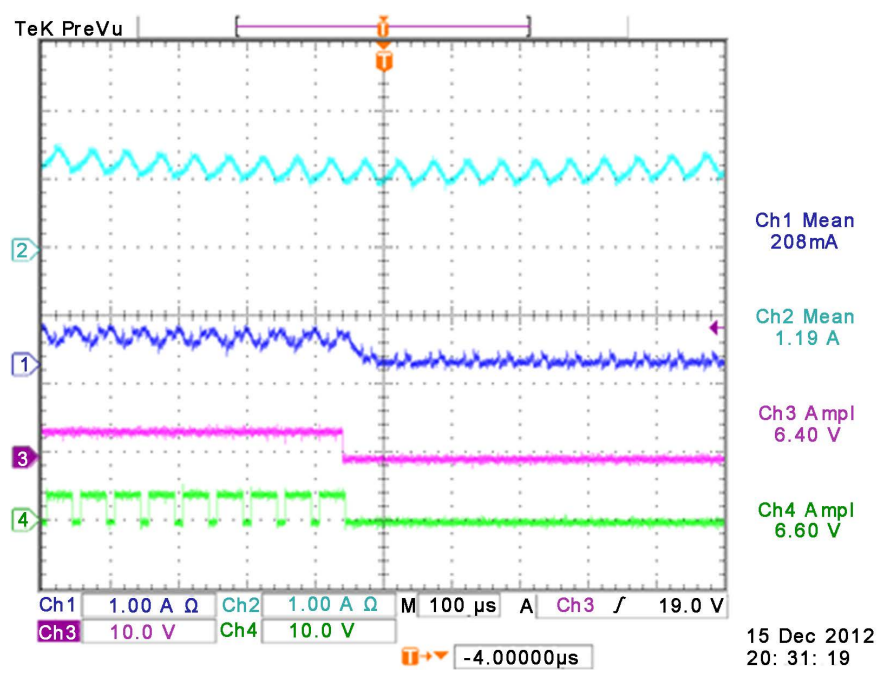

Figure 10. Response of the novel control to the PV power decrease due to irradiation fall.

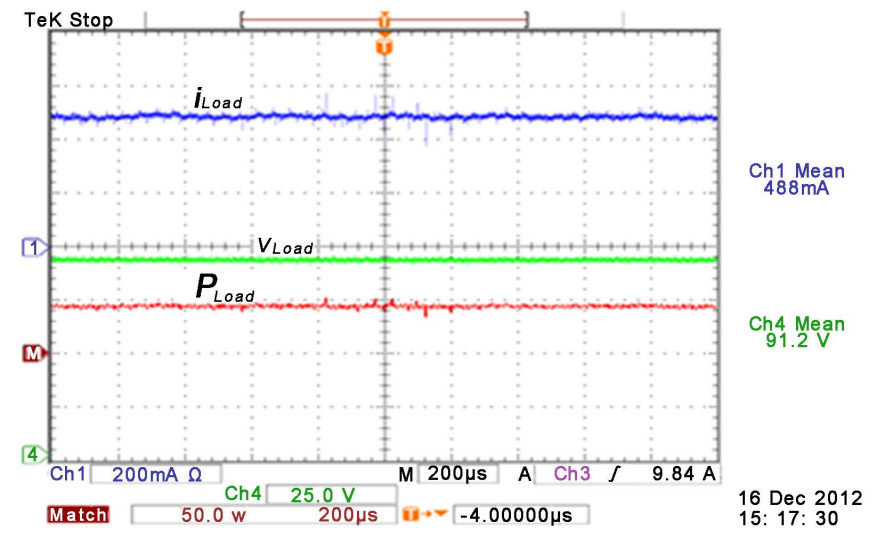

Figure 11. Load current, voltage, and load power of interleaved boost converters with novel switch adaptive control at irradiation $=1000 \mathrm{w} / \mathrm{m}^{2}, 25^{\circ} \mathrm{C}$. 
about 44.5 Watts. The output current and voltage of interleaved boost converter with novel switch adaptive control have unseen ripple in comparing with conventional boost converter.

The maximum current and voltage of PV panel in conventional and interleaved boost converter are obtained under different irradiation condition levels. As can be seen the input current ripple amplitude of interleaved boost converter is smaller than the conventional boost converter, also the interleaved has more output ripple frequency. But the interleaved boost converter at low PV power, its current operates in discontinues current mode. The proposed interleaved boost converter with novel switch adaptive control as shown under $150 \mathrm{w} / \mathrm{m}^{2}, 25^{\circ} \mathrm{C}$ using switch with its designed control to isolate one limb of interleaved to inject all small current of PV at low irradiation in one leg to void discontinuous current mode and still give the same advantages of interleaved boost converter at high power level.

The experimental efficiency results for the conventional boost converter under various conditions are shown in Figure 12, the axis (x) represents the maximum PV power that goes up as the irradiation weather rises which is shown on the right axis (y). While the left axis (y) represents the efficiency of the conventional boost converter with different load percentage. The efficiency of the conventional boost converter; with its load of about $100 \%$ (195 ohms) and at low irradiation $150 \mathrm{w} / \mathrm{m}^{2}, 25^{\circ} \mathrm{C}$ (available PV power of 7 Watts), is $91.73 \%$. At 250 $\mathrm{w} / \mathrm{m}^{2}, 25^{\circ} \mathrm{C}$ (available PV power of $12 \mathrm{Watts}$ ), the efficiency is steady until 550 $\mathrm{w} / \mathrm{m}^{2}, 25^{\circ} \mathrm{C}$. As the irradiation and maximum PV power continue to rise, the efficiency of the converter starts to decline until it reaches $89.08 \%$ at irradiation $1000 \mathrm{w} / \mathrm{m}^{2}, 25^{\circ} \mathrm{C}$ (available PV power of 50 Watts). With $50 \%$ load $(100 \mathrm{ohm}$ ), the converter shows a similar trend, the converter shows high efficiency $92.98 \%$ at irradiation $200 \mathrm{w} / \mathrm{m}^{2}, 25^{\circ} \mathrm{C}$ with maximum obtainable array power $9.93 \mathrm{Watts}$. Then, the converter efficiency starts to decrease as the maximum PV power increases. Eventually, when the irradiation is at $1000 \mathrm{w} / \mathrm{m}^{2}, 25^{\circ} \mathrm{C}$ available PV power of 50 Watts), the efficiency of the converter is at its lowest level of $87.94 \%$.

The results from the interleaved boost converter are presented in Figure 13, the left axis (y) represents the efficiency of the interleaved boost converter with different load percentages and axis ( $\mathrm{x}$ ) presents the maximum PV power that rises as the irradiation weather rises which is shown on the right axis (y). As the result on the whole figure indicates, the efficiency of the interleaved boost converter with its load of about $50 \%(100 \mathrm{Ohms})$, at low irradiation $150 \mathrm{w} / \mathrm{m}^{2}, 25^{\circ} \mathrm{C}$ with available generated maximum PV power of about 7 Watts, the converter shows low efficiency of $90.02 \%$ and after a slight climb at $250 \mathrm{w} / \mathrm{m}^{2}, 25^{\circ} \mathrm{C}$ that produced the available maximum PV power of 12 Watts, after that the high level efficiency nearly starts to be steady as can be seen at irradiation levels $400 \mathrm{w} / \mathrm{m}^{2}$, $25^{\circ} \mathrm{C}, 500 \mathrm{w} / \mathrm{m}^{2}, 25^{\circ} \mathrm{C}$, at $750 \mathrm{w} / \mathrm{m}^{2}, 25^{\circ} \mathrm{C}$ as the obtained maximum $\mathrm{PV}$ power rises until the efficiency of the converter reaches $91.48 \%$ at irradiation 1000 $\mathrm{w} / \mathrm{m}^{2}, 25^{\circ} \mathrm{C}$ and maximum PV power 50 Watts. Also, the converter with (195 Ohm) 100 percentage of its load shows nearly the same trace, the converter has 


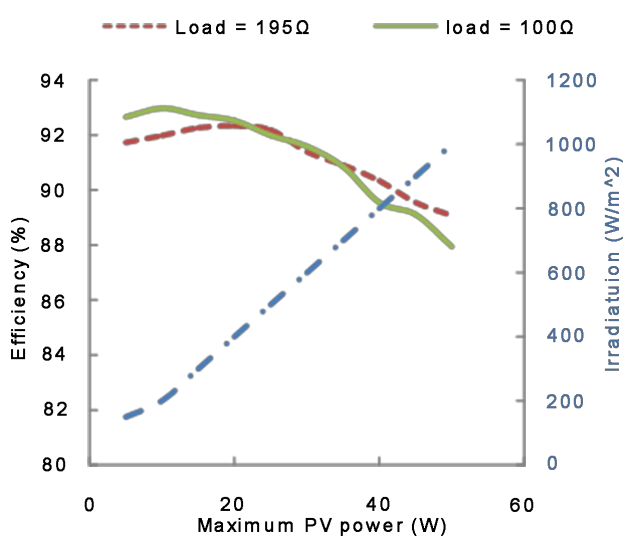

Figure 12. Efficiency results of hardware experimental to conventional boost converter with different load value under irradiation atmosphere condition.

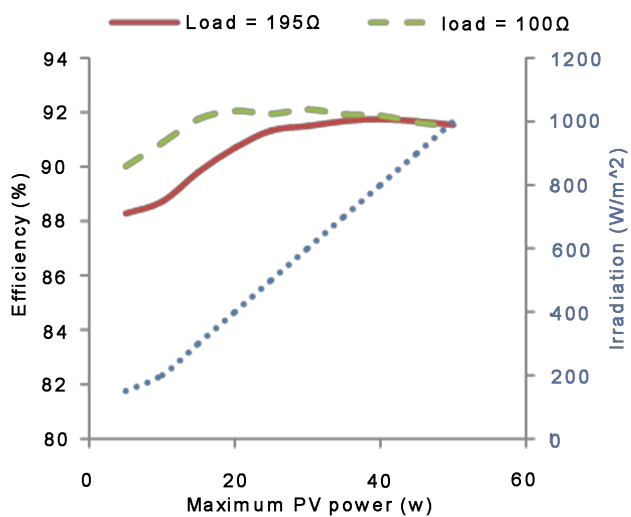

Figure 13. Efficiency results of hardware experimental to interleaved boost converter with different load value under irradiation atmosphere condition.

shown a high efficiency level around $91.60 \%$ at irradiation $600 \mathrm{w} / \mathrm{m}^{2}, 25^{\circ} \mathrm{C}, 700$ $\mathrm{w} / \mathrm{m}^{2}, 25^{\circ} \mathrm{C}, 800 \mathrm{w} / \mathrm{m}^{2}, 25^{\circ} \mathrm{C}$ and $900 \mathrm{w} / \mathrm{m}^{2}, 25^{\circ} \mathrm{C}$ with maximum obtainable array power, but the converter shows a low efficiency when the maximum PV power reduces due to the decrease of the irradiations, for example, at $150 \mathrm{w} / \mathrm{m}^{2}$, $25^{\circ} \mathrm{C}$ with gained maximum power 7 Watts, the efficiency of the converter goes to the lowest level of $88.28 \%$.

Efficiency results for the interleaved boost converter with novel switch adaptive control (under various tests of atmospheric conditions and variable resistive load) are shown in Figure 14. As can be seen, the left axis (y) represents the efficiency of the converter with different load percentages, and axis (x) represents the maximum PV power that rises as the irradiation weather takes off that is shown on the right axis (y). The efficiency of the interleaved boost converter with novel switch adaptive control under $50 \%$ (100 ohms) of its load, with low irradiation $150 \mathrm{w} / \mathrm{m}^{2}, 25^{\circ} \mathrm{C}$ and maximum available PV power of about 7 Watts, is $92.14 \%$. After climbing to $300 \mathrm{w} / \mathrm{m}^{2}, 25^{\circ} \mathrm{C}$ and maximum available PV power of 15 Watts, the high efficiency level starts remain steady; as can be seen by 


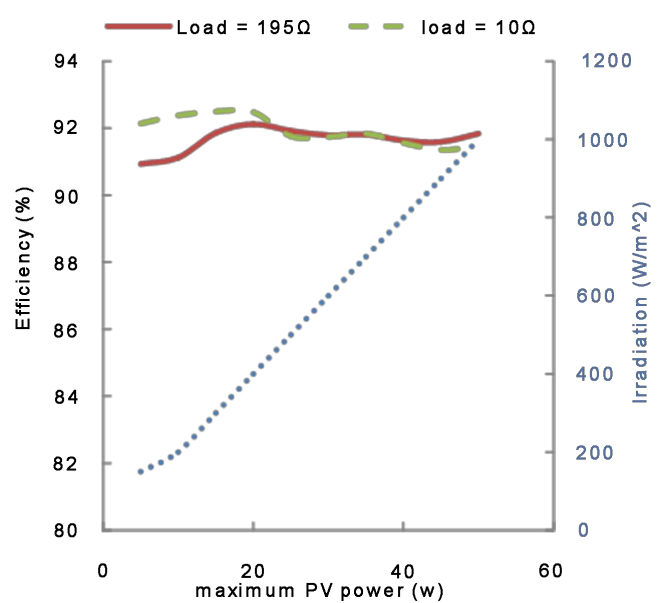

Figure 14. Efficiency results of hardware experimental to interleaved boost converter with novel switch adaptive control under irradiation atmosphere condition and load percentages.

similar results at irradiation levels of $450 \mathrm{w} / \mathrm{m}^{2}, 25^{\circ} \mathrm{C}$ and $600 \mathrm{w} / \mathrm{m}^{2}, 25^{\circ} \mathrm{C}$. At $1000 \mathrm{w} / \mathrm{m}^{2}, 25^{\circ} \mathrm{C}$, at near maximum PV power, the efficiency of the converter reaches $91.46 \%$. Moreover, with 100 percentage $(195 \mathrm{ohm})$ a similar trend is observed; the converter shows the efficiency level to be around $91.9 \%$ at irradiation $400 \mathrm{w} / \mathrm{m}^{2}, 25^{\circ} \mathrm{C}, 600 \mathrm{w} / \mathrm{m}^{2}, 25^{\circ} \mathrm{C}$, and $900 \mathrm{w} / \mathrm{m}^{2}, 25^{\circ} \mathrm{C}$ with maximum obtainable array power, but the converter shows a lower efficiency of $91.9 \%$ at $150 \mathrm{w} / \mathrm{m}^{2}$, $25^{\circ} \mathrm{C}$ and $200 \mathrm{w} / \mathrm{m}^{2}, 25^{\circ} \mathrm{C}$ when the maximum PV power reduces due to the decrease in irradiation.

\section{Conclusion}

This work designed a novel switch adaptive control to improve the efficiency of interleaved boost converter in photovoltaic system under changeable irradiation condition. The interleaved boost converter circuit has very attractive features, such as low current ripple at the input and output stages, low device stress. Furthermore, by adding the novel switch adaptive control, it promises to operate in continued current mode with different levels of power, and high efficiency for both low power and high power of photovoltaic panel under atmosphere conditions. With consideration to varied load conditions, the results of simulation and experiment confirm the advantages mentioned earlier, and that make an interleaved boost converter with novel switch adaptive control, convincing choice to be used for changeable input power of PV system applications.

\section{References}

[1] Chihchiang, H., Jongrong, L. and Chihming, S. (1998) Implementation of a DSP-Controlled Photovoltaic System with Peak Power Tracking. IEEE Transactions on Industrial Electronics, 45, 99-107. https://doi.org/10.1109/41.661310

[2] Veerachary, M., Senjyu, T. and Uezato, K. (2003) Neural Network-Based MaximumPower-Point Tracking of Coupled-Inductor Interleaved-Boost-Converter-Supplied PV System Using Fuzzy Controller. IEEE Transactions on Industrial Electronics, 50, 
749-758. https://doi.org/10.1109/TIE.2003.814762

[3] Dolara, A., Faranda, R. and Leva, S. (2009) Energy Comparison of Seven MPPT Techniques for PV Systems. Journal of Electromagnetic Analysis and Applications, 1, 152-162. https://doi.org/10.4236/jemaa.2009.13024

[4] Chih-Yu, Y., Chun-Yu, H., Fu-Kuei, F. and Ke-Horng, C. (2012) Highly Efficient Analog Maximum Power Point Tracking (AMPPT) in a Photovoltaic System. IEEE Transactions on Circuits and Systems I: Regular Papers, 59, 1546-1556. https://doi.org/10.1109/TCSI.2011.2177008

[5] Esram, T. and Chapman, P.L. (2007) Comparison of Photovoltaic Array Maximum Power Point Tracking Techniques. IEEE Transactions on Energy Conversion, 22, 439-449. https://doi.org/10.1109/TEC.2006.874230

[6] Faranda, R. and Leva, S. (2008) Energy Comparison of MPPT Techniques for PV Systems. Wseas Transactions on Power Systems, 3, 447-455.

[7] Sera, D., Kerekes, T., Teodorescu, R. and Blaabjerg, F. (2006) Improved MPPT Method for Rapidly Changing Environmental Conditions. IEEE International Symposium on Industrial Electronics, 2, 1420-1425.

https://doi.org/10.1109/isie.2006.295680

[8] Yu, W.S., Qian, H. and Lai, J.-S (2010) Design of High-Efficiency Bidirectional DC-DC Converter and High-Precision Efficiency Measurement. IEEE Transactions on Power Electronics, 25, 650-658.

https://doi.org/10.1109/TPEL.2009.2034265

[9] Berasategi, A., Cabal, C., Alonso, C. and Estibals, B. (2009) European Efficiency Improvement in Photovoltaic Applications by Means of Parallel Connection of Power Converters. Proceedings of the 13 th European Conference on Power Electronics and Applications, 8-10 September 2009, 1-10.

[10] Sarnago, H., Mediano, A. and Lucia, O. (2012) High Efficiency AC-AC Power Electronic Converter Applied to Domestic Induction Heating. IEEE Transactions on Power Electronics, 27, 676-3684. https://doi.org/10.1109/TPEL.2012.2185067

[11] Qun, Z. and Lee, F.C. (2003) High-Efficiency, High Step-Up DC-DC Converters. IEEE Transactions on Power Electronics, 18, 65-73. https://doi.org/10.1109/TPEL.2002.807188

[12] Dwari, S. and Parsa, L. An Efficient High-Step-Up Interleaved DC-DC Converter with a Common Active Clamp. IEEE Transactions on Power Electronics, 26, 66-78. https://doi.org/10.1109/TPEL.2010.2051816

[13] Li, W.H., Zhao, Y., Deng, Y. and He, X.N. (2010) Interleaved Converter with Voltage Multiplier Cell for High Step-Up and High-Efficiency Conversion. IEEE Transactions on Power Electronics, 25, 2397-2408.

https://doi.org/10.1109/TPEL.2010.2048340

[14] Watanabe, K., Campelo, F., Iijima, Y., Kawano, K., Matsuo, T., Mifune, T. and Igarashi, H. (2010) Optimization of Inductors Using Evolutionary Algorithms and Its Experimental Validation. IEEE Transactions on Magnetics, 46, 3393-3396. https://doi.org/10.1109/TMAG.2010.2044986

[15] Kobayashi, Y., Ishibashi, S., Shirakawa, K., Toriu, J., Matsuki, H. and Murakami, K. (1992) New Type Micro Cloth-Inductor and Transformer with Thin Amorphous Wires and Multi-Thin Coils. IEEE Transactions on Magnetics, 28, 3012-3014. https://doi.org/10.1109/20.179701

[16] Eyssa, Y.M., Abdelsalam, M.K., Boom, R.W., Huang, X., McIntosh, G.E. and Waynert, J. (1989) Design and Optimization of Hydrogen Cooled Pulsed Storage Inductors for Electromagnetic Launchers. IEEE Transactions on Magnetics, 25, 174-179. https://doi.org/10.1109/20.22529 
[17] Kulkarni, J.P., Augustine, C., Byunghoo, J. and Roy, K. (2010) Nano Spiral Inductors for Low-Power Digital Spintronic Circuits. IEEE Transactions on Magnetics, 46, 1898-1901. https://doi.org/10.1109/TMAG.2010.2046020

[18] Weitzel, C.E., Palmour, J.W., Carter, C.H., Moore, J.K., Nordquist, K.K., Allen, S., Thero, C. and Bhatnagar, M. (1996) Silicon Carbide High-Power Devices. IEEE Transactions on Electron Devices, 43, 1732-1741. https://doi.org/10.1109/16.536819

[19] Wa, L.P., Yim, S.L., Cheng, D.K.W. and Xiu, L.C. (2000) Steady-State Analysis of an Interleaved Boost Converter with Coupled Inductors. IEEE Transactions on Industrial Electronics, 47, 787-795. https://doi.org/10.1109/41.857959

[20] Veerachary, M., Senjyu, T. and Uezato, K. (2003) Maximum Power Point Tracking of Coupled Inductor Interleaved Boost Converter Supplied PV System. IEEE Proceedings of Electric Power Applications, 150, 71-80.

https://doi.org/10.1049/ip-epa:20020686

[21] Bidoggia, B., Spiazzi, G., Buso, S., Lequeu, T. and Ventura, L. (2008) Design of a Fuel Cell Based Backup System for Telecoms Applications. Proceedings of IEEE 30 th International in Telecommunications Energy Conference, 2008, 1-8. https://doi.org/10.1109/intlec.2008.4664030

[22] Seyezhai, R. (2011) Design Consideration of Interleaved Boost Converter for Fuel Cell Systems. SSN College of Engineering, Chennai.

\section{Submit or recommend next manuscript to SCIRP and we will provide best} service for you:

Accepting pre-submission inquiries through Email, Facebook, LinkedIn, Twitter, etc. A wide selection of journals (inclusive of 9 subjects, more than 200 journals)

Providing 24-hour high-quality service

User-friendly online submission system

Fair and swift peer-review system

Efficient typesetting and proofreading procedure

Display of the result of downloads and visits, as well as the number of cited articles

Maximum dissemination of your research work

Submit your manuscript at: http://papersubmission.scirp.org/

Or contact jpee@scirp.org 